Volume 10 Number 4, October-December 2016: pp. 605-820. Copyright (c) 2015-2016 FIAT JUSTISIA. Faculty of Law, Lampung University, Bandarlampung, Lampung, Indonesia. ISSN: 1978-5186 | e-ISSN: 2477-6238.

Open Access: http://jurnal.fh.unila.ac.id/index.php/fiat

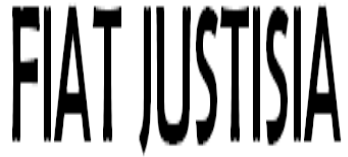

Fiat Justisia is licensed under a Creative Commons Attribution 4.0 International License, which permits unrestricted use, distribution, and reproduction in any medium, provided the original work is properly cited.

\title{
PERALIHAN PENGELOLAAN BARANG MILIK DAERAH BERUPA TANAH DALAM PENYELENGGARAAN PENDIDIKAN SMA/SMK DI PROVINSI LAMPUNG
}

\author{
Transition of Regional Assets Management Form of Land in the \\ Educational Operation for Vocational High School/Senior High School \\ in the Lampung Province
}

\section{Syuratul Kahfi}

Pemerintah Provinsi Lampung

Email: syuratulkahfi@gmail.com

\begin{abstract}
Article 37 paragraph (1) states that the transfer of rights to land and property rights can only be registered if proven by deed made by PPAT authorized under the provisions of the legislation in force. However, based on Circular Letter of the Minister of Agrarian and Spatial Planning/Head of National Land Agency Number: 1855/15.1/IV/2016 dated April 22, 2016 on Implementation Guidelines for Land Registration Government Agencies, so that government agencies in this government of Lampung Province has specificity (Lex Specialist derogat legi generalist) and ease in order titling and completion certificate of land that became assets.
\end{abstract}

Keywords: Transition, Regional Assets (Land), Secondary Education.

\begin{abstract}
Abstrak
Pasal 37 ayat (1) yang menyatakan bahwa peralihan hak atas tanah dan hak milik hanya dapat didaftarkan jika dibuktikan dengan akta yang dibuat oleh PPAT yang berwenang menurut ketentuan peraturan perundang-undangan yang berlaku. Namun, berdasarkan Surat Edaran Menteri Agraria dan Tata Ruang/Kepala Badan Pertanahan Nasional Nomor: 1855/15.1/IV/2016 tanggal 22 April 2016 tentang Petunjuk Pelaksanaan Pendaftaran Tanah Instansi Pemerintah, sehingga instansi pemerintah dalam hal ini pemerintah Provinsi Lampung mempunyai kekhususan (Lex Specialis Derogat Legi
\end{abstract}


Generalis) dan kemudahan dalam rangka pengurusan hak dan penyelesaian sertifikat tanah-tanah yang menjadi asetnya.

Kata kunci: Peralihan, Barang Milik Daerah (tanah), Pendidikan Menengah

\section{A. Pendahuluan}

Pada tanggal 30 September 2014 lahir Undang-Undang Nomor 23 Tahun 2014 tentang Pemerintahan Daerah. Undang-Undang Nomor 23 tahun 2014 tentang Pemerintahan Daerah yang mengatur tentang pembagian urusan pemerintahan antara pemerintah pusat, pemerintah provinsi dan pemerintah kabupaten/kota akan menyebabkan terjadinya perubahan pada organisasi pemerintah daerah di Indonesia. Perubahan ini terjadi terkait adanya pelimpahan kewenangan dari pemerintah kabupaten/kota ke pemerintah provinsi pada sub urusan pengelolaan pendidikan menengah, urusan kehutanan, urusan energi dan sumber daya mineral (ESDM), urusan kelautan dan perikanan, pengelolaan terminal, kewenangan metrologi dan kewenangan ketenagakerjaan.

Penerapan Undang-Undang Nomor 23 Tahun 2014 tentang Pemerintahan Daerah ini tentu akan berdampak terhadap sistem informasi pengelolaan aset daerah khususnya terjadi pada pelimpahan kewenangan urusan pengelolaan pendidikan menengah (Sekolah Menengah Atas Negeri dan Sekolah Menengah Kejuruan Negeri) karena pelimpahan kewenangan ini juga menyebabkan adanya pelimpahan aset dari pemerintah kabupaten/kota ke pemerintah provinsi. Kewenangan pengelolaan aset sebagai akibat pembagian urusan konkuren, akan diikuti dengan integrasi sistem informasi pengelolaan aset daerah pada seluruh SMAN dan SMKN yang akan dialihkan dari pemerintah kabupaten/kota ke Pemerintah Provinsi Lampung.

Mobilisasi tanah yang semula merupakan barang milik daerah kabupaten/kota menjadi barang milik daerah provinsi. Tanah yang semula bersertifikat atas nama pemerintah kabupaten/kota harus dipindahtangankan atau dialihkan kepada pemerintah provinsi. Pemindahtanganan atau pengalihan hak atas tanah tersebut harus didaftarkan ke kantor pertanahan. Dengan kata lain sertifikat tanah harus dibalik nama atas nama pemerintah provinsi, untuk sebuah jaminan kepastian hukum. ${ }^{1}$

Beberapa kendala yang timbul dalam proses pengalihan aset ini diantaranya seperti data aset SMA/SMK di kabupaten/kota yang diserahkan oleh Badan Pengelolaan Keuangan dan Aset Daerah (BPKAD) di kabupaten/kota ke Pemerintah Provinsi Lampung melalui Biro Perlengkapan

\footnotetext{
${ }^{1}$ Smith, Roger. (2015). "Land Registration: Rectification and Purchaserss". The Cambridge
} Law Journal, 74(1): 10-13. 
dan Aset Daerah tidak sesuai dengan kondisi riil yang ada pada sekolahsekolah tersebut. Sedangkan khusus kendala yang berkaitan dengan tanah di SMA/SMK yang pengelolaannya akan diserahkan oleh pemerintah kabupaten/kota ke pemerintah provinsi diantaranya banyaknya tanah yang belum mempunyai sertifikat, adanya tanah yang diperoleh dari dana komite sekolah yang akta jual belinya atas nama perorangan (kepala desa/ketua komite), adanya tanah yang diperoleh dari hibah masyarakat tetapi sampai saat ini belum dilakukannya proses persertifikatan atas nama pemerintah daerah maupun atas nama sekolah yang bersangkutan, adanya ketidaksingkronan antara luas tanah yang tercatat pada akta jual beli dengan luas tanah riil yang ada dilapangan, dan banyaknya sertifikat asli tanah yang tidak diketahui keberadaanyan baik dari pihak sekolah maupun dari pihak pemerintah kabupaten/kota.

Adapun permasalahan yang diangkat penulis untuk dibahas adalah :

1. Bagaimanakah pengaturan tentang peralihan barang milik daerah berupa tanah dalam penyelenggaraan pendidikan SMA/SMK di Provinsi Lampung?

2. Bagaimanakah proses peralihan pengelolaan barang milik daerah berupa tanah bidang pendidikan SMA/SMK di Provinsi Lampung?

\section{B. Pembahasan}

\section{Pengaturan Tentang Peralihan Barang Milik Daerah (Tanah) SMA/SMK di Provinsi Lampung}

Undang-Undang Nomor 23 Tahun 2014 membagi urusan pemerintahan menjadi 3 urusan, yaitu urusan pemerintahan absolut, urusan pemerintahan konkuren, dan urusan pemerintahan umum. Urusan pemerintahan absolut adalah urusan pemerintahan yang sepenuhnya menjadi kewenangan pemerintah pusat, urusan pemerintahan konkuren adalah urusan pemerintahan yang dibagi antara pemerintah pusat dan daerah provinsi dan daerah kabupaten/kota, dan urusan pemerintahan umum adalah urusan pemerintahan yang menjadi kewenangan presiden sebagai kepala pemerintahan. Urusan pemerintahan konkuren yang diserahkan ke daerah inilah yang menjadi dasar pelaksanakan otonomi daerah. ${ }^{2}$

Implementasi Undang-Undang Nomor 23 Tahun 2014 ini menyebabkan terjadinya perubahan pada organisasi pemerintah daerah di Indonesia. Perubahan ini terjadi terkait adanya pelimpahan kewenangan dari pemerintah kabupaten/kota ke pemerintah provinsi pada sub urusan pengelolaan pendidikan menengah, urusan kehutanan, urusan ESDM, urusan kelautan dan perikanan, pengelolaan terminal, kewenangan metrologi dan

\footnotetext{
${ }^{2}$ Pasal 9 Undang-Undang 23 Tahun 2014 tentang Pemerintahan Daerah.
} 
kewenangan ketenagakerjaan. Undang-undang inilah yang menjadi dasar hukum pengalihan urusan kewenangan pengelolaan pendidikan menengah (SMA/SMK) dari pemerintah kabupaten/kota ke pemerintah provinsi. Dalam undang-undang tersebut dicantumkan soal pembagian urusan pemerintahan dalam hal pengelolaan pendidikan antara pemerintah pusat, provinsi, dan kabupaten/kota. Manajemen pengelolaan SMA/SMK berada di tangan pemerintah provinsi, sementara pemerintah kabupaten/kota hanya menangani sekolah dasar dan sekolah menengah pertama.

Menurut Meydiandra EP selaku Kepala Bagian Penyimpanan dan Penatausahaan Barang Daerah Provinsi Lampung, khusus pada pengalihan kewenangan pendidikan menengah dan pendidikan khusus, terdapat pengalihan aset dari kurang lebih 218 Sekolah Menengah Atas Negeri (SMAN) dan 84 Sekolah Menengah Kejuruan Negeri (SMKN) dari pemerintah kabupaten/kota di Provinsi Lampung ke Pemerintah Provinsi Lampung. Dampak dari pengalihan urusan/kewenangan terhadap pengelolaan aset daerah antara lain adalah meningkatnya pengelolaan aset daerah.

Menurut Wayan Purwanajata, Kasubbag Monitoring, Evaluasi, dan Penyusunan Neraca Barang Daerah pada Biro Perlengkapan dan Aset Daerah Setda Provinsi Lampung menyatakan bahwa dalam pelaksanaan proses peralihan kewenangan ini tidak disertai aturan khusus atau peraturan pemerintah sebagai turunan dari Undang-Undang Nomor 23 Tahun 2014. Sedangkan pelaksaan ketentuan undang-undang ini diberi tenggat waktu, karena dalam Pasal 404 Undang-Undang 23 Tahun 2014 tentang Pemerintah Daerah disebutkan bahwa serah terima personel, pendanaan, sarana dan prasarana, serta dokumen sebagai akibat pembagian urusan pemerintahan antara pemerintah pusat, daerah provinsi dan daerah kabupaten/kota yang diatur berdasarkan undang-undang ini dilakukan paling lama 2 (dua) tahun terhitung sejak undang-undang ini diundangkan. Akibatnya, pemerintah daerah kebingungan ketika menerapkan sejumlah ketentuan di undangundang tersebut.

Berdasarkan ketentuan Peraturan Menteri Dalam Negeri Nomor 19 Tahun 2016 tentang Pedoman Pengelolaan Barang Milik Daerah Bab X Pasal 329 ayat (1) dan (2), disebutkan bahwa barang milik daerah dapat dipindahtangankan dengan cara :

a. Penjualan;

b. Tukar menukar;

c. Hibah, dan

d. Penyertaan modal pemerintah daerah. ${ }^{3}$

\footnotetext{
${ }^{3}$ Pasal 329 ayat (1) dan (2) Peraturan Menteri Dalam Negeri Nomor 19 Tahun 2016 tentang Pedoman Pengelolaan Barang Milik Daerah.
} 
Pelaksanaan pelimpahan aset kali ini mengikuti ketentuan UndangUndang Nomor 23 Tahun 2014 tentang Pemerintahan Daerah yang penekanannya terdapat pada Pasal 404. Sebagai tindak lanjut, pemerintah pusat dalam hal ini Menteri Dalam Negeri mengeluarkan Surat Edaran Menteri Dalam Negeri Nomor: 120/253/SJ tanggal 16 Januari 2015 Perihal Penyelenggaraan Urusan Pemerintahan setelah ditetapkan Undang-Undang Nomor 23 Tahun 2014 tentang Pemerintahan Daerah, kemudian Surat Edaran Menteri Dalam Negeri yang ke dua No.120/5935/SJ tanggal 16 Oktober 2015 tentang Percepatan Pelaksanaan Pengalihan Urusan Berdasarkan UU No. 23 tahun 2014 tentang Pemerintahan Daerah. Khusus pada Provinsi Lampung, pemerintah daerah Lampung telah menerbitkan Surat Keputusan Gubernur Lampung Nomor G/442/B.II/HK/2015 Tanggal 10 September 2015 Tentang Pembentukan Tim Inventarisasi Penyerahan Personil, Pendanaan, Sarana dan Prasarana serta Dokumen dari Kab/Kota se Provinsi Lampung.

\section{Proses Peralihan Pengelolaan Barang Milik Daerah berupa Tanah Bidang Pendidikan SMA/SMK Negeri di Provinsi Lampung}

Pasal 404 Undang-Undang Nomor 23 Tahun 2014 tentang Pemerintahan Daerah menyatakan bahwa serah terima Personel, Pendanaan, Sarana dan Prasarana, serta Dokumen sebagai akibat pembagian urusan pemerintahan antara Pemerintah Pusat, Daerah Provinsi dan Daerah Kab/Kota yang diatur dalam Undang-Undang Nomor 23 Tahun 2014, dilakukan paling lama 2 (dua) tahun terhitung sejak Undang-Undang Nomor 23 Tahun 2014 diundangkan. Kemudian dalam Surat Edaran Menteri Dalam Negeri Nomor 120/5935/SJ tanggal 16 Oktober 2015 disebutkan bahwa proses Inventarisasi Personel, Sarana dan Prasarana, Pendanaan dan Dokumen sebagai akibat pengalihan urusan pemerintahan konkruen paling lambat dilaksanakan tanggal 31 Maret 2016. Inventarisasi aset yang akan dialihkan kewenangannya dari kabupaten/kota ke pemerintah Provinsi Lampung harus selesai dilaksanakan sebelum tanggal 31 Maret 2016.

Edi Firdaus, sebagai Koordinator Tim Pelimpahan P3D Biro Perlengkapan \& Aset Daerah Provinsi Lampung mengemukakan bahwa pada proses pelimpahan kewenangan ini, Biro Perlengkapan \& Aset Daerah Provinsi terkendala karena tidak adanya peraturan turunan dari UndangUndang Nomor 23 Tahun 2014 sebagai aturan atau acuan khusus proses pelimpahan ini. Padahal semestinya setiap undang-undang ketika pelaksanaannya seharusnya ada peraturan turunan, akan tetapi pada Undang- 
Undang Nomor 23 Tahun 2014 ini pemerintah pusat belum mengeluarkan peraturan turunan $(\mathrm{PP})$.

Hal yang sama dinyatakan oleh Putut Indarwanto Kepala Bagian Aset Kabupaten Pringsewu, bahwa dalam pelaksanaan pelimpahan kewenangan ini Kabupaten Pringewu kesulitan karena tidak adanya aturan khusus sebagai acuan pelimpahan aset dari kabupaten/kota ke provinsi. Pemerintah pusat hanya mengeluarkan berupa Surat Edaran Mendagri sehingga pemerintah daerah dalam pelaksanaan penyerahan aset ini tidak di dukung peraturan khusus yang baku.

Pada saat ini pemerintah Provinsi Lampung telah sampai kepada tahap pengumpulan alas hak pendukung tanah-tanah yang ada pada SMA/SMK di kabupaten/kota seluruh Provinsi Lampung (berupa alas hak fotocopy). Kemudian seluruh alas hak asli tanah yang ada pada SMA/SMK di kabupaten/kota seluruh Provinsi Lampung akan ditarik oleh pemerintah Provinsi Lampung ketika proses pelaksanakan serah terima antara pemerintah kabupaten/kota (bupati/walikota) se Provinsi Lampung dengan pemerintah daerah Provinsi Lampung (gubernur) pada tanggal 2 Oktober 2016.

Proses serah terima tersebut akan dilakukan dalam acara resmi tentang penandatanganan berita acara serah terima personel, sarana dan prasarana dan dokumen yang akan dihadiri oleh Gubernur Lampung, bupati/walikota se-Provinsi Lampung, unsur Kementerian/LPNK, Ketua DPRD provinsi dan kab/kota dan Kepala Kejaksaan Tinggi Provinsi Lampung serta Kepala Kejaksaan Negeri Kab/Kota se-Provinsi Lampung (sesuai lampiran SE. Mendagri Nomor 120/5935/SJ Tanggal 16 Oktober 2015).

Sedangkan proses balik nama sertifikat SMA/SMK dari atas nama pemerintah daerah kabupaten/kota menjadi atas nama pemerintah daerah provinsi atau pendaftaran tanah atas nama pemerintah daerah provinsi, dapat dilakukan oleh pemerintah daerah provinsi ketika proses pengalihan kewenangan telah selesai dilaksanakan ditandai dengan penyerahan seluruh alas hak yang dimiliki oleh pemerintah kabupaten/kota disertai dengan berita acara penyerahan yang ditandatangani oleh bupati/walikota.

Menurut Mujahiddin sebagai kepala kantor BPN Kabupaten Lampung Tengah, mengemukakan bahwa ketika mau balik nama atau mendaftarkan sertifikat tanah, gubernur melalui sekretaris daerah membuat surat pernyataan bahwa tanah tersebut memang benar telah beralih menjadi aset pemerintah daerah provinsi dalam hal ini Provinsi Lampung dan juga aset tersebut tidak dalam sengketa apapun sehingga dibuat surat permohonan untuk balik nama dari aset pemerintah kabupaten/kota menjadi atas nama 
pemerintah provinsi dalam hal ini Provinsi Lampung. Begitupun untuk tanah yang belum punya sertifikat untuk diterbitkan sertifikat atas nama pemerintah provinsi dalam hal ini Provinsi Lampung.

Pada saat hendak mengajukan proses balik nama aset pemerintah kabupaten menjadi aset pemerintah provinsi maupun proses persertifikatan tanah yang belum bersetifikat hal-hal yang harus dipersiapkan antara lain :

a. Berita acara serah terima aset;

b. Berita acara pelepasan hak dari kabupaten/kota;

c. Surat pernyataan dari gubernur melaui sekretaris daerah yang menerangkan bahwa aset yang dimaksud telah beralih kepemilikan dari aset kabupaten/kota menjadi aset provinsi dan aset tersebut telah tercatat pada buku aset provinsi;

d. Alas hak sebagai bukti kepemilikan yang ada;

e. Surat pernyataan penguasaan fisik yang ditandatangani oleh bupati/walikota yang disaksikan oleh minimal 2 (dua) orang saksi untuk tanah SMA/SMK yang belum bersertifikat;

f. Setelah itu pemerintah provinsi membuat permohonan balik nama ke kantor BPN kabupaten/kota setempat untuk dapat diterbitkan sertifikat maupun merubah data kepemilikan lainnya, dan juga mendaftarkan tanah-tanah yang belum bersertifikat (tanah mentah) dengan atas nama pemerintah provinsi.

Hal yang sama dinyatakan oleh Oki MP sebagai Kasubsi Peralihan Hak Badan Pertanahan Kota Bandar Lampung, yang menyatakan bahwa mengingat masih banyaknya aset-aset instansi pemerintah yang belum terdaftar, maka dalam rangka untuk menjamin kepastian hukum hak atas tanah instansi pemerintah perlu diberikan kemudahan dan percepatan bagi instansi pemerintah yang akan mendaftarkan tanahnya, yang mana hal tersebut dituangkan dalam Surat Edaran Menteri Agraria dan Tata Ruang/Kepala Badan Pertanahan Nasional Nomor : 1855/15.1/IV/2016 tanggal 22 April 2016 tentang Petunjuk Pelaksanaan Pendaftaran Tanah Instansi Pemerintah.

Oki MP melanjutkan bahwa setelah ditandatanganinya berita acara serah terima aset yang didasari atas perintah undang-undang tersebut, secara yuridis aset itu beralih dari pemerintah kabupaten/kota ke pemerintah provinsi. Dimana tahapannya pemerintah kabupaten/kota harus terlebih dahulu mengeluarkan aset tersebut dari daftar SIMDA aset pemerintah kabupaten/kota, untuk selanjutnya aset tersebut dimasukan ke SIMDA aset pemerintah provinsi. Tahapan selanjutnya berdasarkan bukti kepemilikan yang ada itu mendaftarkan permohonan haknya pada kantor pertanahan 
kabupaten/kota melalui unit kerja subseksi pendaftaran tanah instansi pemerintah dan harus memenuhi persyaratan sesuai Peraturan Pemerintah No. 128 Tahun 2015 dan Peraturan Pemerintah No. 1 Tahun 2010.

Meskipun instansi pemerintah dalam proses pendaftaran tanahnya mendapatkan kemudahan, instansi pemerintah tetap harus memperhatikan angka 3 Surat Edaran Menteri Agraria dan Tata Ruang/Kepala Badan Pertanahan Nasional Nomor : 1855/15.1/IV/2016 yang menyatakan bahwa tanah yang dimohonkan haruslah dalam keadaan Clean and Clear yaitu tidak terdapat keberatan dari pihak lain atas tanah yang dikuasai (tidak sengketa) atau tidak dalam pendudukan/occupatie oleh pihak lain serta telah tercatat dalam daftar inventaris aset instansi pemerintah yang bersangkutan.

Berdasarkan data yang diperoleh dari Biro Perlengkapan dan Aset Daerah Provinsi Lampung, nilai aset yang diserahkan oleh pemerintah kabupaten/kota se Provinsi Lampung ke pemerintah Provinsi Lampung adalah senilai Rp. 890.775.894.508,26,- dan dari nilai tersebut khusus aset tanah senilai Rp. 317.615.815.390,-.

Tabel 1: Nilai aset yang diserahkan oleh Pemerintah Kabupaten/Kota se-Provinsi Lampung ke Pemerintah Provinsi Lampung

\begin{tabular}{|c|l|r|r|r|r|}
\hline \multirow{2}{*}{ No } & \multirow{2}{*}{ KAB/KOTA } & \multicolumn{2}{|c|}{ SEKOLAH } & \multicolumn{2}{|c|}{ NILAI } \\
\cline { 3 - 6 } & & SMA & SMK & \multicolumn{1}{c|}{ TANAH } & SELURUH ASET \\
\hline 1 & Way Kanan & 23 & 12 & $646,184,850$ & $40,483,836,165.79$ \\
\hline 2 & $\begin{array}{l}\text { Tulang Bawang } \\
\text { Barat }\end{array}$ & 12 & 2 & $27,250,510,000$ & $81,721,124,912$ \\
\hline 3 & Tulang Bawang & 14 & 7 & $16,199,418,800$ & $50,925,475,379$ \\
\hline 4 & Tanggamus & 17 & 4 & $4,260,750,003$ & $51,209,662,350$ \\
\hline 5 & Pringsewu & 10 & 3 & $9,598,480,050$ & $35,681,366,776$ \\
\hline 6 & Pesisir Barat & 8 & 2 & $4,693,770,000$ & $52,881,493,817$ \\
\hline 7 & Pesawaran & 13 & 4 & $405,368,000$ & $5,439,052,020$ \\
\hline 8 & Metro & 5 & 5 & $33,233,569,900$ & $35,557,793,557$ \\
\hline 9 & Mesuji & 7 & 5 & $4,555,100,004$ & $7,403,014,092.70$ \\
\hline 10 & $\begin{array}{l}\text { Lampung } \\
\text { Selatan }\end{array}$ & 16 & 9 & $5,207,141,000$ & $83,704,877,529$ \\
\hline
\end{tabular}




\begin{tabular}{|c|l|r|r|r|r|}
\hline 11 & Lampung Utara & 21 & 8 & $10,968,000,000$ & $73,867,105,651.06$ \\
\hline 12 & $\begin{array}{l}\text { Lampung } \\
\text { Timur }\end{array}$ & 20 & 7 & $5,241,945,640$ & $48,815,869,456.48$ \\
\hline 13 & Lampung Barat & 13 & 5 & $7,836,709,800$ & $79,364,420,702.67$ \\
\hline 14 & $\begin{array}{l}\text { Bandar } \\
\text { Lampung }\end{array}$ & 17 & 8 & $116,312,789,002$ & $186,786,096,098.15$ \\
\hline 15 & $\begin{array}{l}\text { Lampung } \\
\text { Tengah }\end{array}$ & 23 & 9 & $7,285,854,684$ & $59,258,929,658.41$ \\
\hline & JUMLAH & $\mathbf{2 1 9}$ & $\mathbf{9 0}$ & $\mathbf{2 5 3 , 6 9 5 , 5 9 1 , 7 3 3}$ & $\mathbf{8 9 3 , 1 0 0 , 1 1 8 , 1 6 5 . 2 6}$ \\
\hline
\end{tabular}

Sumber: Data sekunder 2016 dari Biro Perlengkapan dan Aset Daerah Provinsi Lampung, diolah

Wayan Purwanajata sebagai Kasubbag Monitoring, Evaluasi, dan Penyusunan Neraca Barang Daerah pada Biro Perlengkapan dan Aset Daerah Setda Provinsi Lampung menjelaskan bahwa nilai tersebut diperoleh dari neraca pemerintah kabupaten/kota yang telah diaudit oleh Badan Pemeriksa Keuangan Per Desember 2015. Sehingga pada aset yang diserahkan oleh pemerintah kabupaten/kota ini nilainya belum menggambarkan kondisi sebenarnya. Disebabkan masih terdapat beberapa aset yang belum dimasukkan nilai perolehannya, dikarenakan aset tersebut belum tercatat pada SIMDA pemerintah kabupaten/kota.

Begitu juga khusus yang berkaitan dengan aset tanah, terdapat perbedaan jumlah tanah antara aset tanah yang diserahkan dengan data tanah yang tercatat pada neraca masing-masing pemerintah kabupaten/kota se Provinsi Lampung. Sehingga nilai aset khususnya pada aset tanah yang diserahkan pada Provinsi Lampung belum menggambarkan kondisi yang sebenarnya. Hal tersebut dikarenakan masih terdapatnya aset tanah yang diperoleh oleh pihak sekolah tetapi tidak dilaporkan pada Dinas Pendidikan atau Badan Pengelolaan Keuangan dan Aset Daerah di kabupaten/kota.

Sampai dengan penulisan ini selesai dilakukan (Oktober 2016), pemerintah kabupaten/kota yang telah melaporkan secara rinci aset tanah SMA/SMK Negeri ke pemerintah Provinsi Lampung terdapat 8 (delapan) kabupaten/kota. Secara ringkas dapat di tampilkan pada tabel berikut, dan secara rinci ditampilkan pada lampiran tesis. 
Tabel 2: Aset Tanah SMA/SMK Negeri pada 8 (delapan) Pemerintah Kabupaten/Kota yang diserahkan kepada Pemerintah Provinsi Lampung

\begin{tabular}{|c|l|r|r|r|}
\hline \multirow{2}{*}{ No. } & \multirow{2}{*}{ Kabupaten/kota } & \multicolumn{2}{|c|}{ Aset tanah } & \multirow{2}{*}{ Sumlah } \\
\cline { 3 - 5 } & & Sertifikat & $\begin{array}{c}\text { Belum } \\
\text { Sertifikat }\end{array}$ & \\
\hline 1 & Kabupaten Pesawaran & 8 & 9 & 17 \\
\hline 2 & Kabupaten Lampung Utara & 11 & 17 & 28 \\
\hline 3 & Kota Bandar Lampung & 20 & 5 & 25 \\
\hline 4 & Kota Metro & 9 & 1 & 10 \\
\hline 5 & Kabupaten Pringsewu & 9 & 4 & 13 \\
\hline 6 & Kabupaten Tulang Bawang & 6 & 15 & 21 \\
\hline 7 & Kabupaten Mesuji & 10 & 6 & 16 \\
\hline 8 & Kabupaten Pesisir Barat & 4 & 7 & 11 \\
\hline & JUMLAH & $\mathbf{7 7}$ & $\mathbf{6 4}$ & $\mathbf{1 4 1}$ \\
\hline
\end{tabular}

Sumber: Data sekunder 2016 dari Biro Perlengkapan dan Aset Daerah Provinsi Lampung, diolah.

Aset pemerintah memang banyak yang tidak mempunyai sertifikat, bahkan aset-aset tanah yang telah bersertifikatpun belum semuanya atas nama pemerintah kabupaten/kota masing-masing, karena masih terdapatnya sertifikat dengan atas nama Departemen Pendidikan Nasional atau Kanwil Pendidikan dan Kebudayaan tetapi secara fisik aset-aset tersebut telah dikuasai dan telah dipergunakan. Sehingga pada saat proses balik nama atau pendaftaran tanah, pemerintah harus membuat surat pernyataan penguasaan fisik bidang tanah berdasarkan keterangan yang sebenar-benarnya dan pihak yang membuat pernyataan bertanggungjawab baik secara perdata maupun pidana apabila dikemudian hari terdapat unsur-unsur ketidakbenaran dalam pernyataannya dan bersedia sertifikatnya dibatalkan dan diproses hukum sesuai peraturan yang berlaku.

Pada saat proses pendaftaran tanah, tanah pemerintah memang tidak serumit tanah masyarakat. Sehingga pada saat mengajukan pendaftaran tanah SMA/SMK Negeri yang belum bersertifikat ke BPN, gubernur melalui 
sekretaris daerah cukup hanya dengan menjamin (surat pernyataan) bahwa tanah tersebut memang benar merupakan aset provinsi dan tidak dalam sengketa.

Sedangkan untuk sertifikat yang hilang, pemerintah kabupaten/kota setempat harus melapor kepada pihak kepolisian. Selanjutnya pihak kepolisian akan mengumumkan selama 2 (dua) bulan berturut-turut melalui koran, jika tidak terdapat sanggahan maka pihak BPN kabupaten/kota setempat akan menerbitkan sertifikat baru dan pada saat terbit setifikat baru, di dalam sertifikat baru tersebut akan dicantumkan pernyataan yang menyatakan bahwa sertifikat yang lama tidak berlaku lagi, dan apabila dikemudian hari sertifikat lama tersebut diketemukan maka diharuskan melaporkan sertifikat tersebut ke kantor BPN setempat untuk dinonaktifkan.

Menurut Nova Mayora sebagai Kasubsi Pendaftaran Hak pada kantor BPN Kabupaten Pesawaran, persertifikatan tanah maupun proses balik nama merupakan bagian dari pemeliharaan data yang disebut continous recording (pencatatan yang terus menerus). Karena sesuai tujuan pendaftaran tanah yang terdapat dalam Pasal 3 Peraturan Pemerintah Nomor 24 Tahun 1997 tentang Pendaftaran Tanah adalah :

a. Untuk memberikan kepastian hukum dan perlindungan hukum kepada pemegang hak atas suatu bidang tanah, satuan bidang rumah susun dan hak-hak lain yang terdaftar agar dengan mudah dapat membuktikan dirinya sebagai pemegang hak yang bersangkutan;

b. Untuk menyediakan informasi kepada pihak-pihak yang berkepentingan termasuk pemerintah agar dengan mudah dapat membuktikan dirinya sebagai pemegang hak yang bersangkutan;

c. Untuk terselenggaranya tertib administrasi pertanahan.

Sedangkan menurut FX. Sumarja, dalam bukunya mengatakan bahwa yang dimaksud dengan pendaftaran tanah adalah rangkaian kegiatan yang dilakukan oleh pemerintah secara terus menerus berkesinambungan dan teratur meliputi pengumpulan, pengolahan, pembukuan, dan penyajian serta pemeliharaan data fisik dan data yuridis, dalam bentuk peta dan daftar, mengenai bidang-bidang tanah dan satuan-satuan rumah susun, termasuk pemberian sertifikat sebagai surat tanda bukti haknya bagi bidang-bidang tanah yang sudah ada haknya dan hak milik atas satuan rumah susun serta hak-hak tertentu yang membebaninya. ${ }^{4}$

Berdasarkan penjelasan di atas, dapat disimpulkan bahwa tujuan daripada pendaftaran tanah adalah untuk memberikan kepastian terhadap

\footnotetext{
${ }^{4}$ Op. Cit. p. 20.
} 
obyek tanah, hak, dan kepastian subyeknya. Banyaknya permasalahan yang timbul dari kepemilikan tanah maka pendaftaran tanah juga untuk mengantisipasi segala bentuk perselisihan yang mungkin terjadi, maka oleh undang-undang pemilik hak (dalam hal ini pemerintah daerah) wajib mendaftarkan tanah yang menjadi haknya, agar tidak terjadi sesuatu yang merugikan dikemudian hari, sebagaimana disebutkan pada Pasal 4 ayat (3) Peraturan Pemerintah Nomor 24 Tahun 1997 tentang Pendaftaran Tanah yang berbunyi sebagai berikut : "Untuk mencapai tertib administrasi setiap bidang tanah dan satuan rumah susun termasuk peralihan, pembebanan dan hapusnya hak atas bidang tanah dan hak milik atas satuan rumah susun wajib didaftarkan".

Dengan demikian hak atas suatu bidang tanah harus didaftarkan haknya pada kantor pertanahan setempat dimana tanah itu berada. Disamping merupakan kewajiban dari pemilik tanah dalam hal ini pemerintah daerah, pendaftaran tanah juga untuk melaksanakan Pasal 3 huruf c Peraturan Pemerintah Nomor 24 Tahun 1997 tentang Pendaftaran Tanah yang berbunyi : "Pendaftaran tanah bertujuan untuk terselenggaranya tertib administrasi pertanahan".

Sehingga dengan mendaftarkan kepemilikan hak atas bidang tanah tersebut maka pemiliknya mempunyai kepastian, kekuatan dan perlindungan hukum atas kepemilikan tanahnya. Dalam rangka memberikan jaminan kepastian dan perlindungan hukum, tentang kedudukan, status tanah agar tidak terjadi sengketa dan kesalahpahaman baik mengenai batas maupun siapa pemiliknya, maka Undang-Undang Pokok Agraria sebagai suatu undang-undang yang memuat dasar-dasar pokok dibidang agraria yang merupakan landasan bagi usaha pembaharuan hukum agraria untuk memberikan jaminan kepastian hukum bagi masyarakat dalam memanfaatkan fungsi bumi, air, dan ruang angkasa serta kekayaan alam yang terkandung di dalamnya untuk kesejahteraan bersama secara adil. Tujuan Undang-Undang Pokok Agraria antara lain menjamin kepastian hukum. Untuk mencapai tujuan tersebut, Undang-Undang Pokok Agraria telah mengatur pendaftaran tanah yaitu dalam Pasal 19 ayat (1) UndangUndang Pokok Agraria yang berbunyi: "Untuk menjamin kepastian hukum oleh Pemerintah diadakan pendaftaran tanah diseluruh wilayah Indonesia menurut kepastian hukum oleh pemerintah diadakan pendaftaran tanah di seluruh wilayah Indonesia menurut ketentuan yang diatur dengan Peraturan Pemerintah."

Sedangkan terkait dengan beralihnya kepemilikan akibat dari peralihan pengelolaan aset ini dapat dilaksanakan karena merupakan 
perintah undang-undang. Walaupun pada Pasal 37 ayat (1) yang menyatakan bahwa peralihan hak atas tanah dan hak milik hanya dapat didaftarkan jika dibuktikan dengan akta yang dibuat oleh PPAT yang berwenang menurut ketentuan peraturan perundang-undangan yang berlaku. Namun, berdasarkan Surat Edaran Menteri Agraria dan Tata Ruang/Kepala Badan Pertanahan Nasional Nomor : 1855/15.1/IV/2016 tanggal 22 April 2016 tentang Petunjuk Pelaksanaan Pendaftaran Tanah Instansi Pemerintah, sehingga instansi pemerintah dalam hal ini pemerintah Provinsi Lampung mempunyai kekhususan (Lex Specialis Derogat Legi Generalis) dan kemudahan dalam rangka pengurusan hak dan penyelesaian sertifikat tanah-tanah yang menjadi asetnya.

\section{Penutup}

\section{Simpulan}

Implementasi Undang-undang Nomor 23 Tahun 2014 ini menyebabkan terjadinya perubahan pada organisasi pemerintah daerah di Indonesia. Perubahan ini terjadi terkait adanya pelimpahan kewenangan dari pemerintah kabupaten/kota ke pemerintah provinsi yang salah satunya urusan pengelolaan pendidikan menengah. Undang-undang inilah yang menjadi dasar hukum pengalihan urusan kewenangan pengelolaan pendidikan menengah (SMA/SMK) dari pemerintah kabupaten/kota ke pemerintah provinsi yang penekanannya terdapat pada Pasal 404 UndangUndang Nomor 23 Tahun 2014 tentang Pemerintahan Daerah.

Namun dalam pelaksanaan Undang-Undang Nomor 23 Tahun 2014 tersebut pemerintah provinsi maupun pemerintah kabupaten/kota mengalami kesulitan, dikarenakan pemerintah pusat tidak mengeluarkan peraturan turunan dari Undang-Undang Nomor 23 Tahun 2014 yaitu Peraturan Pemerintah (PP) sebagai acuan bagi pemerintah daerah dalam pelaksanaan dari perintah undang-undang tersebut. Pemerintah pusat dalam hal ini Menteri Dalam Negeri hanya mengeluarkan Surat Edaran Menteri Dalam Negeri Nomor: 120/253/SJ tanggal 16 Januari 2015 dan Surat Edaran Menteri Dalam Negeri yang ke dua Nomor : 120/5935/SJ tanggal 16 Oktober 2015 tentang Percepatan Pelaksanaan Pengalihan Urusan Berdasarkan Undang-Undang Nomor 23 Tahun 2014 tentang Pemerintahan Daerah.

Proses balik nama sertifikat SMA/SMK dari atas nama pemerintah kabupaten/kota menjadi atas nama pemerintah provinsi atau pendaftaran tanah atas nama pemerintah provinsi, dilakukan oleh pemerintah provinsi 
ketika proses pengalihan kewenangan telah selesai dilaksanakan. Ditandai dengan penyerahan seluruh alas hak tanah yang dimiliki oleh pemerintah kabupaten/kota disertai dengan penandatanganan berita acara penyerahan antara pemerintah kabupaten/kota (bupati/walikota) di Provinsi Lampung dengan pemerintah Provinsi Lampung (gubernur) yang akan dilaksanakan pada tanggal 2 Oktober 2016.

Peralihan pengelolaan aset ini dapat dilaksanakan karena merupakan perintah undang-undang. Walaupun pada Pasal 37 ayat (1) yang menyatakan bahwa peralihan hak atas tanah dan hak milik hanya dapat didaftarkan jika dibuktikan dengan akta yang dibuat oleh PPAT yang berwenang menurut ketentuan peraturan perundang-undangan yang berlaku. Namun, berdasarkan Surat Edaran Menteri Agraria dan Tata Ruang/Kepala Badan Pertanahan Nasional Nomor: 1855/15.1/IV/2016 tanggal 22 April 2016 tentang Petunjuk Pelaksanaan Pendaftaran Tanah Instansi Pemerintah, sehingga instansi pemerintah dalam hal ini pemerintah Provinsi Lampung mempunyai kekhususan (Lex Specialis Derogat Legi Generalis) dan kemudahan dalam rangka pengurusan hak dan penyelesaian sertifikat tanah-tanah yang menjadi asetnya.

\section{Saran}

a. Dalam pelaksanaan Undang-Undang Nomor 23 Tahun 2014 tentang Pemerintah Daerah, pemerintah provinsi maupun pemerintah kabupaten/kota mengalami kesulitan dikarenakan pemerintah pusat tidak mengeluarkan peraturan turunan dari Undang-Undang Nomor 23 Tahun 2014 yaitu Peraturan Pemerintah (PP) sebagai acuan bagi pemerintah daerah dalam pelaksanaan dari perintah undang-undang tersebut. Oleh karena itu, ketika pemerintah pusat mengeluarkan suatu undang-undang, penulis menyarankan hendaknya pemerintah pusat segera mengeluarkan peraturan turunan, sehingga dalam pelaksanaan perintah undang-undang tersebut, pemerintah provinsi dan/atau pemerintah kabupaten/kota tidak mengalami kesulitan.

b. Karena banyaknya manfaat sekaligus permasalahan yang timbul dan bersumber dari kepemilikan tanah. Untuk mengantisipasi segala bentuk perselisihan yang mungkin terjadi, maka oleh undang-undang pemilik hak wajib mendaftarkan tanah yang menjadi haknya pada kantor pertanahan setempat dimana tanah itu berada. Disamping merupakan kewajiban dari pemilik tanah, pendaftaran tanah juga untuk melaksanakan Pasal 3 huruf c Peraturan Pemerintah Nomor 24 Tahun 1997 tentang Pendaftaran Tanah yang berbunyi : "Pendaftaran tanah 
bertujuan untuk terselenggaranya tertib administrasi pertanahan". Oleh karena itu, setelah proses pengalihan kewenangan ini selesai, disarankan kepada pemerintah provinsi dalam hal ini Biro Perlengkapan dan Aset Daerah Provinsi segera menyelesaikan proses persertifikatan untuk tanah yang belum bersertifikat dan proses balik nama dengan dibantu oleh pihak sekolah dan pemerintah kabupaten/kota yang menyerahkan aset tanah tersebut.

\section{Daftar Pustaka}

\section{A. Jurnal dan Data Pendukung}

Smith, Roger. (2015). "Land Registration: Rectification and Purchaserss", The Cambridge Law Journal, 74(1): 10-13.

Data sekunder 2016 dari Biro Perlengkapan dan Aset Daerah Provinsi Lampung.

\section{B. Peraturan Perundang-Undangan}

Undang-Undang 23 Tahun 2014 tentang Pemerintahan Daerah.

Peraturan Menteri Dalam Negeri Nomor 19 Tahun 2016 tentang Pedoman Pengelolaan Barang Milik Daerah. 
